\title{
Inflammatory arthritis in HIV positive patients: A practical guide
}

\author{
T. Adizie' ${ }^{1}$ R. J. Moots ${ }^{2,3^{*}}$, B. Hodkinson ${ }^{4}$, N. French ${ }^{5}$ and A. O. Adebajo ${ }^{6}$
}

\begin{abstract}
Background: Musculoskeletal manifestations of the human immunodeficiency virus (HIV) have been described since the outset of the global HIV epidemic. Articular syndromes that have been described in association with HIV include HIV-associated arthropathy, seronegative spondyloarthropathies (SPA) (reactive arthritis, psoriatic arthritis (PsA) and undifferentiated SPA), rheumatoid arthritis (RA) and painful articular syndrome.

Methods: We carried out a computer-assisted search of PubMed for the medical literature from January 1981 to January 2015 using the keywords HIV, acquired immune-deficiency syndrome, rheumatic manifestations, arthritis, spondyloarthropathy, anti-TNF and disease modifying antirheumatic drugs. Only English language literature was included and only studies involving adult human subjects were assessed.
\end{abstract}

Results: There are challenges in the management of inflammatory arthritis in patients who are HIV-positive, including difficulties in the assessment of disease activity and limited information on the safety of immunosuppressive drugs in these individuals.

Conclusions: This review focuses on the clinical characteristics of the inflammatory articular syndromes that have been described in association with HIV infection and discusses the therapeutic options for these patients.

Keywords: HIV, Acquired immune-deficiency syndrome, Rheumatic manifestations, Arthritis, Spondyloarthropathy, anti-TNF and Disease modifying antirheumatic drugs

\section{Background}

Musculoskeletal manifestations of the human immunodeficiency virus (HIV) have been described since the outset of the global HIV epidemic. The first reports of rheumatological symptoms of the infection occurred 3 years after its discovery, with Winchester et al. describing a case of reactive arthritis in a patient with advanced acquired immunodeficiency syndrome (AIDS) [1]. Substantial gains have been made at stemming the spread of HIV, with the rate of new cases each year steadily declining and the number of AIDS-related deaths also falling from 3.1 million in 2005 to 1.7 million in 2012 [2]. HIV positive patients are also living longer due to antiretroviral (ARV) therapy and as a result, chronic noncommunicable diseases in long-term sufferers of HIV are now emerging as a significant cause of morbidity.

\footnotetext{
* Correspondence: rjmoots@liv.ac.uk

${ }^{2}$ Rheumatology Department, Aintree University Hospital, Liverpool, UK

${ }^{3}$ Clinical Sciences Centre, Aintree University Hospital, Longmoor Lane,

Liverpool L9 7AL, UK

Full list of author information is available at the end of the article
}

Patients infected with HIV have been shown to have a higher risk of developing rheumatic diseases [3], and this can occur at any stage of the disease. Moreover, HIV positive patients having musculoskeletal involvement have reduced quality of life, when compared to those without rheumatic symptoms [4]. Articular syndromes that have been described in association with HIV include HIV-associated arthropathy, seronegative spondyloarthropathies (SPA) (reactive arthritis, psoriatic arthritis (PsA) and undifferentiated SPA), rheumatoid arthritis (RA) and painful articular syndrome. Other nonarticular rheumatological conditions including osteonecrosis, vasculitis and myositis are well described manifestations of HIV but are not within the scope of this article. This review focuses on the clinical characteristics of the inflammatory articular syndromes that have been described in association with HIV infection and discusses the therapeutic options for these patients. 


\section{Methods}

We carried out a computer-assisted search of PubMed and google scholar for the medical literature from January 1981 to January 2015 using the keywords HIV, acquired immune-deficiency syndrome, rheumatic manifestations, arthritis, spondyloarthropathy, anti-TNF and disease modifying antirheumatic drugs. Only English language literature was included and only studies involving adult human subjects were assessed (Fig. 1).

\section{Results}

\section{HIV-associated Arthropathy}

HIV-associated arthritis can occur at any stage of HIV illness. It presents as an asymmetric oligo arthritis, symmetrical polyarthritis or as a monoarthritis. The asymmetric, oligo arthritis variant is the most common form, has a male preponderance, and predominately affects the knees and ankles [5]. The symmetrical polyarthritis variant closely mimics $\mathrm{RA}$, with patients exhibiting similar deformities to rheumatoid patients, including ulnar deviation. It is characterised however by greater acuity at onset and is usually nonerosive. The presence of Jaccoud arthropathy as part of an HIV-associated arthritis has also been described occasionally [6]. HIV-associated arthritis tends to be short lived with its peak intensity occurring in 1 to 6 weeks [7]. However, some patients develop a chronic destructive arthropathy, associated with marked functional disability [8]. Features of mucocutaneous involvement or enthesopathy are rare. Radiological changes can occasionally mimic RA, with joint space narrowing, erosions and periarticular osteopenia [5]. However, some patients demonstrate new bone formation - a radiological finding unusual in RA [9]. There is an inflammatory, but sterile pattern on synovial fluid analysis with white cell count in the region of $50-2600$ cells $/ \mu \mathrm{L}$, and normal glucose [5]. ANA, Rheumatoid Factor and HLA B27 are negative [10]. There remains considerable debate as to whether HIV infection is the cause of, or a coincidental finding in patients who are HIV positive and seronegative with an inflammatory arthritis. The evidence supporting the hypothesis that HIV has a direct inflammatory effect on synovial tissue is twofold. Firstly, p24 antigen, HIV DNA and tuboreticular inclusions have been detected in the synovial fluid of affected joints [11]. These all point to a viral aetiology. P24 antigen in particular has been found in joints at levels ten times higher than the serum levels [11]. Secondly, there is the epidemiological observation of increased prevalence of rheumatic conditions in HIV positive patients [5]. Some authors have speculated that the true prevalence of $\mathrm{HIV}$-associated arthritis is higher than is generally recorded [11].
Literature Search of databases - Pubmed and Google Scholar. Search terms 'HIV', 'Arthritis', 'Acquired immunodeficiency syndrome', rheumatic manifestations, arthritis, spondyloarthropathy, anti-TNF and disease modifying antirheumatic drugs

Search results combined $(\mathrm{n}=147)$

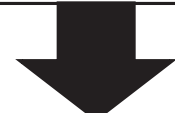

Articles screened on the basis of Title and Abstract

\begin{tabular}{l} 
Excluded $(\mathrm{n}=107)$ \\
Study pertained to septic \\
arthritis( $\mathrm{n}=63)$ \\
Study focused on HIV-negative \\
patients(n=15) \\
Study considered paediatric \\
patients( $\mathrm{n}=8)$ \\
Study included animal \\
subjects $(\mathrm{n}=9)$ \\
Study not in English \\
language $(\mathrm{n}=12)$ \\
\hline
\end{tabular}

Fig. 1 Flowchart of study identification and selection

Painful articular syndrome

The painful articular syndrome is a self-limited disorder of unknown aetiology, lasting for less than $24 \mathrm{~h}$ in patients with HIV infections. It is reported in up to $10 \%$ 
of African HIV-seropositive patients [12] and is noted to be more common in those with advanced infection [13]. Bone and joint pain is noted, especially in the lower extremities in an asymmetric pattern, which is out of proportion to clinical findings. Though synovitis is absent, pain is excruciating and debilitating leading to hospital treatment in more than half of patients. The joints most commonly involved are the knees, shoulders and elbows [11]. Its prevalence appears to have reduced since the advent of HAART [14].

\section{Spondyloarthropathies}

The emergence of HIV has changed the epidemiological profile of rheumatic diseases particularly in sub-Saharan Africa. The SPA were previously described as uncommon in sub-Saharan African due to the rarity of the HLA-B27 allele, but there is an increased prevalence of PsA and reactive arthritis in Africa since the outset of the HIV epidemic [15]. Severe forms of psoriasis and PsA have been reported and are almost universally associated with HIV [16]. This is in contrast to Caucasian HIV positive patients where an increased severity but not prevalence of psoriasis and arthritis is seen [14]. There has been a change in the presentation and severity of these conditions since the widespread use of highly active anti-retroviral therapy [8], with the prevalence of PsA and reactive arthritis declining [14].

\section{Reactive arthritis}

A link between HIV and reactive arthritis has been reported since the early stages of the HIV epidemic. The most typical presentation is that of a seronegative peripheral oligo arthritis predominantly involving the lower extremities, usually accompanied by enthesitis [11]. Mucocutaneous features are common - classically keratoderma blenorrhagicum and circinate balanitis. Skin involvement can be so extensive as to cause diagnostic confusion with PsA [11]. Urethritis occurs in similar frequency to HIV-negative reactive arthritis. Axial involvement and uveitis are uncommon, but do occur. HLA-B27 is found in $80-90 \%$ of Caucasians with HIV-associated reactive arthritis, while studies of Africans with HIV-associated reactive arthritis have found nearly all to be HLA-B27-negative [7]. As in HIV uninfected patients, antecedent history of genitourinary and gastrointestinal infection is common. This point could hold the key to explaining the geographical differences observed in the prevalence of reactive arthritis - countries with higher rates of HIV contracted through intravenous drug use for example, rather than sexual contact, have observed lower rates of reactive arthritis [7].

\section{Psoriatic arthritis}

Along with an increased occurrence, studies suggest that HIV-infected patients with psoriasis have more severe and persistent skin lesions with guttate, inverse and erythrodermic subtypes most common [17]. Similarly, those with joint disease generally suffer a more severe, deforming, erosive arthropathy refractory to conventional treatment [15], with worse clinical features in advanced HIV infection [13]. The onset of psoriatic arthritis in the setting of HIV frequently heralds the development of opportunistic infections [18]. The typical clinical presentation is an asymmetrical oligo- or polyarthritis, with a predilection for the lower limbs [16]. A symmetrical polyarthritis is also described with arthritis mutilans, but distal interphalangeal involvement and axial SPA patterns appear less freqeuntly [16]. Onset may be abrupt, with the development of erosions and disability within weeks. In addition, the number of joints affected tends to increase with time [19].

\section{Undifferentiated spondyloarthropathy}

Some HIV-infected patients fail to develop the entire spectrum of clinical manifestations for disease to be classified as ankylosing spondylitis, reactive arthritis, or PsA, and are labelled as undifferentiated SPA. The predominant rheumatic manifestations exhibited in those with undifferentiated SPA include achilles tendinitis, dactylitis, low-back pain, plantar fasciitis, ankle pain and shoulder pain [11]. Manifestations of keratoderma blenorrhagicum and circinate balanitis are common however a lower frequency of uveitis and axial skeleton involvement is observed [20]. Psoriasiform skin rashes are also common and can be extensive. On magnetic resonance imaging and sonographic imaging, synovitis of the knees, extensive polyenthesitis, and adjacent osteitis are the frequent findings [21].

\section{Rheumatoid arthritis}

The immune dysregulation inherent to HIV infection may interfere with the diagnosis of RA or mimic its clinical presentation. There have been reports of RA arising de novo in HIV positive patients as part of immune reconstitution syndrome following the initiation of anti retroviral therapy [8]. As already stated, HIV-associated arthritis can present as a polyarthritis of the small joints that mimics RA clinically and radiographically. Serological markers of RA can be found in HIV infected patients, and visa versa. Du Toit et al. found positive IgG RF and anti-CCP antibodies in 47 and $15 \%$ of patients with HIV/AIDS respectively, although most patients had low titers [22]. In this study, the antibody titers reduced after 6 months of antiretroviral therapy and no patients developed RA at 1 year follow-up. Conversely, Li et al. found false-positive HIV serology in $16 \%$ of their cohort of Chinese RA patients [23].

Several reports have suggested that patients with established rheumatoid arthritis experience clinical 
Table 1 Summary of clinical characteristics of Inflammatory Articular Syndromes in HIV positive patients

\begin{tabular}{|c|c|c|c|}
\hline \multirow[b]{2}{*}{ Syndrome } & \multicolumn{3}{|l|}{ Clinical characteristics } \\
\hline & HIV negative & HIV Positive & References \\
\hline \multirow[t]{4}{*}{ RA } & $\begin{array}{l}\text { Symmetrical small joint polyarthritis, } \\
\text { hands and feet. }\end{array}$ & $\begin{array}{l}\text { RA activity can improve with HIV } \\
\text { and flare or arise de novo } \\
\text { following HAART }\end{array}$ & \multirow{4}{*}{$\begin{array}{l}\text {-Reveille JD, Williams M. Rheumatologic } \\
\text { complications of HIV infection. Best Practice \& } \\
\text { Research Clinical RheumatologyVol. 20, No. } 6 \\
\text {-du Toit et alLack of specificity of anticyclic } \\
\text { citrullinated peptide antibodies in advanced } \\
\text { human immunodeficiency virus infection. J } \\
\text { Rheumatol 2011;38:1055-60 }\end{array}$} \\
\hline & $\begin{array}{l}\text { Positive Rheumatoid Factor and/or Anti- } \\
\text { CCP }\end{array}$ & $\begin{array}{l}\text { HIV infection itself can be } \\
\text { associated with false positive } \\
\text { Rheumatoid Factor and CCP }\end{array}$ & \\
\hline & \multirow{2}{*}{$\begin{array}{l}\text { Extra articular manifestations such as } \\
\text { interstitial lung disease and rheumatoid } \\
\text { nodules }\end{array}$} & $\begin{array}{l}\text { HIV Arthropathy can mimic } \\
\text { rheumatoid clinically }\end{array}$ & \\
\hline & & $\begin{array}{l}\text { ESR may remain persistently raised } \\
\text { despite good disease control }\end{array}$ & \\
\hline \multirow[t]{4}{*}{ Reactive Arthritis } & \multirow{4}{*}{$\begin{array}{l}\text { Seronegative peripheral oligo arthritis } \\
\text { predominantly involving the lower } \\
\text { extremities, usually accompanied by } \\
\text { enthesitis. Keratoderma blenorrhagicum } \\
\text { and circinate balanitis. }\end{array}$} & $\begin{array}{l}\text { Skin involvement can be more } \\
\text { florid than HIV -ve. }\end{array}$ & \multirow{4}{*}{$\begin{array}{l}\text {-Lawson E, Walker-Bone K. The changing } \\
\text { spectrum of rheumatic disease in HIV infection } \\
\text { Br Med Bull. } 2012 \text { Sep;103(1):203-21 }\end{array}$} \\
\hline & & $\begin{array}{l}\text { Psoriaform rashes can be so } \\
\text { extensive as to cause diagnostic } \\
\text { confusion with PsA. }\end{array}$ & \\
\hline & & $\begin{array}{l}\text { Axial involvement and uveitis are } \\
\text { less common than HIV -ve }\end{array}$ & \\
\hline & & $\begin{array}{l}\text { HLA B27 commoner in Caucasians } \\
\text { than black Africans }\end{array}$ & \\
\hline \multirow[t]{5}{*}{ Psoriatic Arthritis } & Varied presentation: & Typical clinical phenotype is an & \multirow{5}{*}{$\begin{array}{l}\text { Njobvu P, McGill P. Psoriatic arthritis and } \\
\text { human immunodeficiency virus infection in } \\
\text { Zambia. J Rheumatol 2000;27:1699-702 }\end{array}$} \\
\hline & Inflammatory joint pain/spinal pain & $\begin{array}{l}\text { asymmetrical oligo- or } \\
\text { polyarthritis, with a predilection } \\
\text { for the lower limbs }\end{array}$ & \\
\hline & $\begin{array}{l}\text { Distal interphalangeal joint swelling, } \\
\text { dactilytis, symmetrical polyarthritis, } \\
\text { spondylitis, enthesitis and arthritis } \\
\text { mutilans }\end{array}$ & $\begin{array}{l}\text { Can present with an abrupt-onset } \\
\text { florid polyarthritis, particularly in } \\
\text { advanced HIV }\end{array}$ & \\
\hline & \multirow[t]{2}{*}{ History of Psoriasis or family history } & $\begin{array}{l}\text { More severe and persistent skin } \\
\text { lesions with guttate, inverse and } \\
\text { erythrodermic subtypes compared } \\
\text { to HIV -ve }\end{array}$ & \\
\hline & & $\begin{array}{l}\text { Distal interphalangeal involvement } \\
\text { and axial SPA patterns appear less } \\
\text { frequently compared to HIV -ve }\end{array}$ & \\
\hline $\begin{array}{l}\text { Undifferentiated } \\
\text { Spondyloarthropathy }\end{array}$ & $\begin{array}{l}\text { Clinical manifestations of ankylosing } \\
\text { spondylitis, reactive arthritis, or PsA } \\
\text { without full spectrum to be classified as } \\
\text { any syndrome }\end{array}$ & $\begin{array}{l}\text { Achilles tendinitis, dactylitis, low- } \\
\text { back pain, plantar fasciitis, ankle } \\
\text { pain and shoulder pain most } \\
\text { commonly. }\end{array}$ & $\begin{array}{l}\text { Mody G, Parke F. Articular manifestations of } \\
\text { human immunodeficiency virus infection. Best } \\
\text { Practice \& Research Clinical RheumatologyVol. } \\
17, \text { No. 2, pp. 265-287, } 2003\end{array}$ \\
\hline \multirow[t]{3}{*}{$\begin{array}{l}\text { Painful articular } \\
\text { syndrome }\end{array}$} & \multirow[t]{3}{*}{ N/A } & $\begin{array}{l}\text { Severe bone and joint pain in the } \\
\text { lower extremities in an } \\
\text { asymmetric pattern. }\end{array}$ & \multirow{3}{*}{$\begin{array}{l}\text { Reveille JD. The changing spectrum of } \\
\text { rheumatic disease in human } \\
\text { immunodeficiency virus infection. Semin } \\
\text { Arthritis Rheum. 2000;30(3):147 }\end{array}$} \\
\hline & & No objective synovitis. & \\
\hline & & Can be debilitating & \\
\hline \multirow[t]{3}{*}{ HIV Arthropathy } & \multirow[t]{3}{*}{ N/A } & $\begin{array}{l}\text { Presents as an asymmetric oligo } \\
\text { arthritis, symmetrical polyarthritis } \\
\text { or as a monoarthritis. }\end{array}$ & \multirow[t]{3}{*}{$\begin{array}{l}\text { Plate A-M, Boyle B. Musculoskeletal Manifesta- } \\
\text { tions of HIV. AIDS Read. 2003;13(2) }\end{array}$} \\
\hline & & $\begin{array}{l}\text { Patients lack features of } \\
\text { mucocutaneous involvement or } \\
\text { enthesopathy }\end{array}$ & \\
\hline & & $\begin{array}{l}\text { Symmetrical polyarthritis variant } \\
\text { closely mimics RA. }\end{array}$ & \\
\hline
\end{tabular}


Table 1 Summary of clinical characteristics of Inflammatory Articular Syndromes in HIV positive patients (Continued)

\author{
Occasional erosions and joint \\ space narrowing radiographically \\ ANA, Rheumatoid Factor and HLA \\ B27 are negative \\ Sterile, inflammatory synovial fluid
}

improvement after the development of immunodeficiency secondary to HIV [15] Recently, Tarr et al. observed that most HIV positive RA patients in their cohort had lower joint counts and composite disease activity scores despite stopping methotrexate therapy compared to HIV negative controls, supporting the suggestion that HIV infection improves RA disease activity [24]. Their study further highlighted difficulties in monitoring patients with inflammatory arthritis, who happen to be HIV positive. A persistently elevated ESR is a feature of HIV infection [25], and as a result, they demonstrated that the 28 joint count disease activity score (DAS-28) ESR overestimates disease activity by as much as $30 \%$ when compared to DAS28 CRP (Table 1).

\section{Discussion}

Therapy of inflammatory arthritis in HIV positive patients

There are potential issues regarding the safety of disease modifying anti rheumatic drugs (DMARD) and biologic therapy in HIV positive patients, with most available data coming from case series. Non-steroidal anti-inflammatory drugs remain the first line treatment for HIV-associated arthritis. Due to the typically self-limited nature of the condition, DMARDS are rarely required [15]. This is in contrast with the other forms of arthropathy found in association with HIV infection. The arthritis of undifferentiated SPA, and indeed all the SPA can improve significantly with highly active antiretroviral treatment alone [26]. Both the arthritis and the cutaneous lesions of HIV-associated reactive arthritis and PsA have been found to respond to etretinate $(0.5-1.0 \mathrm{mg} / \mathrm{kg} /$ day $)$ according to one report [27].

Interestingly, both Indomethacin and hydroxychloroquine have demonstrated antiretroviral activity in small case series [28-30]. The hydroxychloroquine dose used in one series was $800 \mathrm{mg}$ daily however - a dose not recommended in routine rheumatological practice. Methotrexate was initially viewed as contraindicated in HIV infection due fears of an increased risk of opportunistic infections [31], but is nowadays used cautiously in HIV positive RA and PsA patients with higher CD 4 counts (greater than $100 / \mathrm{mm} 3$ [11]), as long as close monitoring of cell counts is performed [24]. It is still felt though that it should be avoided in those with concomitant hepatitis $\mathrm{C}$ infection [11]. Sulphasalazine (at a dose of 1-2 g daily) has been successfully used to treat SPA with no clinical deterioration in HIV infection [32], and in one reported case even resulted in an improvement in CD 4 count in a patient with reactive arthritis [21]. Leflunomide at a dose of $20 \mathrm{mg}$ daily (used specifically to treat HIV rather than arthritis) has also been shown to reduce HIV replication [33]. Mycophenolate (1 g BD) [34], azathioprine [35] and gold [36] have also been reported to be efficacious in HIV positive patients with PsA. Short courses of prednisolone are also considered safe, even in advanced HIV infection [37]. In one series, Bromocriptine has also been associated with suppression of acute inflammatory arthritis in four out of the five patients with reactive arthritis who failed to respond to sulfasalazine alone. The exact mechanism of its action in the context is not well understood [38].

Biologic DMARDS have been used successfully in HIV positive patients with surprisingly good safety profile. A series of 8 American HIV positive patients had antiTumour Necrosis Factor (anti-TNF) agents (etanercept, adalimumab and infliximab) for different rheumatic conditions (two patients with RA, three with PsA, one with undifferentiated SPA, one with reactive arthritis and one with ankylosing spondylitis) with good efficacy and no adverse effects on their HIV disease [39]. The follow-up in this study was 60 months and the use of the anti-TNF agents was restricted to those with CD4 cell count more than 200 cells $/ \mathrm{ml}$ and viral loads of less than 60000 cop$\mathrm{ies} / \mathrm{ml}$ at the initiation of the therapy [39]. Clearly, these patients need screening for latent tuberculosis and vigilant monitoring for the development of tuberculosis. Most recently, ustekinamab has been used in a patient with psoriasis and PsA previously refractory to methotrexate, adalimumab, etanercept and golimumab. Significant improvement was observed in his skin and joint disease and, after 2 years of therapy, he has maintained a stable CD 4 count (above $800 \mathrm{~mm} 3$ ) and an undetectable viral load while being free of opportunistic infections [40]. There has been one report however of an HIV patient with psoriatic arthritis in whom Etanercept had to be stopped due to recurrent infections [19].

There are several important drug interactions of relevance for HIV positive patients with inflammatory arthritis. For example, ritonavir is a potent inhibitor of liver enzymes CYP3A4 (which metabolises many commonly used glucocorticoids) and CYP2D6. Ritonavir can potently increase the action and duration of action of 
corticosteroids and severe Cushing's syndrome has been reported on several occasions following single intraarticular injections of triamcinolone (usually as Kenalog) for musculoskeletal disease [13]. Therefore triamcinolone preparations should not be administered to patients on ritonavir.

\section{Conclusions}

There are challenges in the management of inflammatory arthritis in patients who are HIV-positive, including difficulties in the assessment of disease activity and limited information on the safety of immunosuppressive drugs in these individuals. Registries for prospective follow up of HIV positive patients with arthropathies are urgently needed to shed light on clinical features and natural history of these conditions, and to develop treatment guidelines.

\section{Abbreviations}

AIDS: Acquired immunodeficiency syndrome; anti-TNF: Anti- Tumour Necrosis Factor; ARV: Antiretroviral; DMARD: Disease modifying anti rheumatic drugs; HIV: Human immunodeficiency virus; PsA: Psoriatic arthritis; RA: Rheumatoid arthritis; SPA: Spondyloarthropathies.

\section{Competing interests}

The authors declare that they have no competing interests.

\section{Authors' contributions}

All authors agreed on the focus and structure of the paper. TA, BH and AOA conducted the literature search. TA, AOA and $\mathrm{BH}$ drafted the first version of the manuscript. RJM and NF contributed substantially to the final version. All authors read and approved the final manuscript.

\section{Acknowledgements}

There are no other parties to acknowledge. No funding bodies were involved in carrying out this research.

\section{Author details}

${ }^{1}$ Rheumatology Department, Heart of England NHS Trust, Birmingham, UK. ${ }^{2}$ Rheumatology Department, Aintree University Hospital, Liverpool, UK. ${ }^{3}$ Clinical Sciences Centre, Aintree University Hospital, Longmoor Lane, Liverpool L9 7AL, UK. ${ }^{4}$ Department of Medicine, Groote Schuur Hospital and University of Cape Town, Cape Town, South Africa. ${ }^{5}$ Department of Clinical Infection, Microbiology \& Immunology, Institute of Infection \& Global Health, The University of Liverpool, Liverpool, UK. ${ }^{6}$ Academic Rheumatology Group, Faculty of Medicine, University of Sheffield, Sheffield, UK.

Received: 25 June 2015 Accepted: 27 January 2016

Published online: 01 March 2016

\section{References}

1. Winchester R, Bernstein D, Fischer H, Enlow R, Solomon G. The cooccurrence of Reiter's syndrome and acquired immunodeficiency. Ann Intern Med. 1987:106:19-26.

2. UNAIDS. Global Report: UNAIDS Report on the Global AIDS Epidemic. 2012. Available from http://www.unaids.org/en/media/unaids/contentassets/ documents/epidemiology/2012/gr2012/20121120_UNAIDS_Global_Report_ 2012_en.pdf.

3. Kaddu-Mukasa M, Ssekasanvu E, Ddumba E, Thomas D, Katabira ET. Rheumatic manifestations among HIV positive adults attending the Infectious disease clinic at Mulago hospital. Afr Health Sci. 2011;11(1):24-9.

4. Kole AK, Roy R, Kole D. Musculoskeletal and rheumatological disorders in HIV infection: Experience in a tertiary referral center. Indian J Sex Transm Dis. 2013;34(2):107-12.

5. Plate A-M, Boyle B. Musculoskeletal Manifestations of HIV. AIDS Read. 2003;13(2):62.
6. Weeratunge NC, Roldan J, Anstead GM. Jaccoud arthropathy: a rarityin the spectrum of HIV-associated arthropathy. Am J Med. 2004;328:351-3.

7. Espinoza LR, García-Valladares I. Microbios y articulaciones: la relación entre infección y articulaciones. Reumatol Clin. 2013:9:229-38.

8. Reveille JD, Williams M. Rheumatologic complications of HIV infection. Best Pract Res Clin Rheumatol. 2006:20(6):1159e1179.

9. Allroggen A, Frese A, Rahmann A, Gaubitz M, Husstedt W, Evers S. HIV associated arthritis: A case report and review of the literature. Eur J Med Res. 2005;10:305-8.

10. Rynes Rl, Goldenberg DL, DIGiacomo R, Olson R, Hussain M, Veazey J. Acquired immunodeficiencysyndrome-associated arthritis. Am J Med. 1988; 84:810-6.

11. Mody G, Parke F. Articular manifestations of humanimmunodeficiency virus infection. Best Pract Res Clin Rheumatol. 2003;17(2):265-87.

12. Reveille JD. The changing spectrum of rheumatic disease in human immunodeficiency virus infection. Semin Arthritis Rheum. 2000;30(3):147.

13. Newton L, van Halsema C, Snowden N. HIV and Rheumatology: A practical guide. ARUK Topical Reviews. Issue 5 (Topical Reviews Series 7) Autumn 2014

14. Keat A. HIV and overlap with Reiter's syndrome. Baillieres Clin Rheumatol. 1994;8(2):363-77.

15. Lawson $\mathrm{E}$, Walker-Bone $\mathrm{K}$. The changing spectrum of rheumatic disease in HIV infection. Br Med Bull. 2012;103(1):203-21.

16. Njobvu P, McGill P. Psoriatic arthritis and human immunodeficiency virus infection in Zambia. J Rheumatol. 2000;27:1699-702.

17. Castillo RL, Racaza GZ, Roa FD. Ostraceous and inverse psoriasis with psoriaticarthritis as the presenting features of advanced HIV infection. Singapore Med J. 2014;55(4):e60-3.

18. Phillips C, Reno H, Atkinson JP, Ranganathan P. HIV presenting as an unusual arthropathy. Arthritis Care Res. 2011;63(3):450-3.

19. Aboulafia DM, Bundow D, Wilske K, Ochs UI. Etanercept for the treatment of human immunodeficiency virus associated arthritis. Mayo Clin Proc. 2000;75: 1093-8.

20. Nguyen B, Reveille J. Rheumatic manifestations associated with HIV in the highly active antiretroviral therapy era. Curr Opin Rheumatol. 2009;21:404-10.

21. Mahajan A, Tandon $V$, Verma S. Rheumatological manifestations in HIV infection. JIACM. 2006:7(2):136-44.

22. du Toit R, Whitelaw D, Taljaard JJ, du Plessis L, Esser M. Lack of specificity of anticyclic citrullinated peptide antibodies in advanced human immunodeficiency virus infection. J Rheumatol. 2011;38:1055-60.

23. Li YC, Yang F, Ji XY, Fang ZJ, Liu J, Wang Y. False human immunodeficiency virus test results associated with rheumatoid factors in rheumatoid arthritis. Chin Med Sci J. 2014:29:103-6.

24. Tarr G, Makda M, Musenge E, Tikly M. Effect of human immunodeficiency virus infection on disease activity in rheumatoid arthritis: a retrospective study in South Africans. J Rheumatol. 2014;41(8):1645-9.

25. Ndakotsu MA, Salawu L, Durosinmi MA. Relation between erythrocyte sedimentation rate, clinical and immune status in HIV-infected patients. Niger J Med. 2009;18(2):208-10.

26. McGonagle D, Reade S, Marzo-Ortega H, Gibbon W, O'Connor P, Morgan A, et al. Human immunodeficiency virus associated spondyloarthropathy: pathogenic insights based on imaging findings and response to highly active antiretroviraltreatment. Ann Rheum Dis. 2001;60:696e698.

27. Louthrenoo W. Successful treatment of severe Reiter's syndrome associated with human immunodeficiency virus infection with etretinate. Report of 2 cases. J Rheumatol. 1993:20:1243-6.

28. Bourinbaiar AS, Lee-Huang S. The non-steroidal anti-inflammatory drug, indomethacin, as an inhibitor of HIV replication. FEBS Lett. 1995;360:85-8.

29. Sperber K, Kalb TH, Stecher VJ, Banerjee R, Mayer L. Inhibition of human immunodeficiency virus type 1 replication by hydroxychloroquine in T cells and monocytes. AIDS Res Hum Retroviruses. 1993;9:91.

30. Sperber K, Louie M, Kraus T, Proner J, Sapira E, Lin S, et al. Hydroxychloroquine treatment of patients with human immunodeficiency virus type 1. Clin Ther. 1995;17:622-36.

31. Masson C, Chennebault JM, Leclech C. Is HIV infection contraindication to the use of methotrexate in psoriatic arthritis? J Rheumatol. 1995;22(11):219.

32. Youssef PP, Bertouch JV, Jones PD. Successful treatment of human immunodeficiency virus-associated Reiter's syndrome with sulfasalazine. Arthritis Rheum. 1992:35:723-4

33. Schläpfer E, Fischer M, Ott P, Speck RF. Anti-HIV-1 activity of leflunomide: a comparison with mycophenolic acid and hydroxyurea. AIDS. 2003;17(11): 1613-20. 
34. Forman $S B$, Higginson R, Garrett AB. Psoriasis and psoriatic arthritis in a patient with HIV: response to mycophenolate mofetil treatment. J Drugs Dermatol. 2008;7(10):972.

35. Maurer TA, Zackheim HS, Tuffanelli L, et al. The use of methotrexate for treatment of psoriasisin patients with HIV infection. J Acad Derm. 1994;31:372-5.

36. Shapiro DL, Masci JR. Treatment of HIV associated psoriatic arthritis with oral gold. J Rheumatol. 1996;23(10):1818-20.

37. Maganti R, Reveille J, Williams F. Therapy insight: the changing spectrum of rheumatic disease in HIV infection. Nat Clin Pract Rheumatol. 2008:4:428-38.

38. Yombi JC, Maiter D, Belkhir L, Nzeusseu A, Vandercam B. latrogenic Cushing's syndrome and secondary adrenal insufficiency after a single intraarticular administration of triamcinolone acetonide in HIV-infected patients treated with ritonavir. Clin Rheumatol. 2008;27 Suppl 2:S79-82.

39. Cepeda EJ, Williams FM, Ishimori ML, Weisman MH, Reveille JD. The use of anti-tumour necrosis factor therapy inHIV-positive individuals with rheumatic disease. Ann Rheum Dis. 2008;67:710-2.

40. Wieder S, Routt E, Levitt J, Lebwohl M. Treatment of refractory psoriasis with ustekinumab in an <? show [?A3B2 show \$6\#?]?>HIV-positive patient: a case presentation and review of the literature. Psoriasis Forum. 2014;20:96-102.

\section{Submit your next manuscript to BioMed Central} and we will help you at every step:

- We accept pre-submission inquiries

- Our selector tool helps you to find the most relevant journal

- We provide round the clock customer support

- Convenient online submission

- Thorough peer review

- Inclusion in PubMed and all major indexing services

- Maximum visibility for your research

Submit your manuscript at www.biomedcentral.com/submit

Biomed Central 